NBER WORKING PAPER SERIES

\title{
THE ANTECEDENTS AND AFTERMATH OF FINANCIAL CRISES AS TOLD BY CARLOS F. DÍAZ ALEJANDRO
}

\author{
Carmen M. Reinhart \\ Working Paper 21350 \\ http://www.nber.org/papers/w21350 \\ NATIONAL BUREAU OF ECONOMIC RESEARCH \\ 1050 Massachusetts Avenue \\ Cambridge, MA 02138 \\ July 2015
}

This paper is based on the lecture delivered at the Carlos Diaz Alejandro Prize awarded for lifelong scholarly contributions to the study of Latin America by the Latin American and Caribbean Economic Association (LACEA), Río de Janeiro, November 2014. I presented an earlier version of the talk at the Eighth Carlos F. Díaz-Alejandro Lecture sponsored by the Association for the Study of the Cuban Economy (ASCE) in Washington DC, April 2011. I wish to thank Guillermo A. Calvo, Graciela L. Kaminsky, Maurice Obstfeld, Vincent Reinhart, Kenneth Rogoff, and seminar participants for helpful comments and suggestions. Ernesto Zedillo, himself a student of Carlos, deserves special thanks for encouraging me during my visit to Yale in 2010 to write about Carlos' contributions. The views expressed herein are those of the author and do not necessarily reflect the views of the National Bureau of Economic Research.

NBER working papers are circulated for discussion and comment purposes. They have not been peerreviewed or been subject to the review by the NBER Board of Directors that accompanies official NBER publications.

(C) 2015 by Carmen M. Reinhart. All rights reserved. Short sections of text, not to exceed two paragraphs, may be quoted without explicit permission provided that full credit, including $(\mathbb{C}$ notice, is given to the source. 
The Antecedents and Aftermath of Financial Crises as told by Carlos F. Díaz Alejandro

Carmen M. Reinhart

NBER Working Paper No. 21350

July 2015

JEL No. B26,E5,E6,F3,G01

\section{$\underline{\text { ABSTRACT }}$}

Some of the best-known papers of Carlos F. Díaz Alejandro were about Latin America's crises in the 1980s and 1930s. I will show data, figures and evidence here about the crises in the advanced economies 30 years later that fit the same narrative. His unadulterated words aptly describe modern problems across geographical borders and, in this case, income levels. This attests to his timeless insight and understanding. Because some of the observations he made have general applicability to the study of recurring patterns across crises, I have taken the liberty to label these as lessons.

Carmen M. Reinhart

Kennedy School of Government

Harvard University

79 JFK Street

Cambridge, MA 02138

and CEPR

and also NBER

carmen_reinhart@harvard.edu 


\section{Introduction}

In preparation for this lecture, I read most of Carlos F. Díaz Alejandro’s works. Some of his papers, especially those most directly connected to financial crises, I had already read and re-read over the course of many years. His influence on how I view the onset, evolution, and aftermath of crisis is undeniable. ${ }^{2}$ In what follows, I begin with a brief biographical note about Díaz Alejandro, who like myself, was born in Habana, Cuba. I, unfortunately, never met him. The remaining discussion is a tour of his works. Since his writing style usually mixes clarity, color, and wit, I have opted to rely extensively on quotes from his writings. Note that throughout these pages italics are Díaz-Alejandro’s own words.

The unifying thread of the narrative is the anatomy and sequence of a financial crisis according to Díaz Alejandro. In some of his best-known papers, he was writing about Latin America's crises in the 1980s. All the data, figures and, evidence I present here is about the crises in the advanced economies 30 years later. The fact that his unadulterated words so aptly describe modern problems attests to his timeless insight and understanding, which applies with force across geographical borders and, in this case, income levels. Because some of the observations he made have general applicability to the study of recurring patterns across crises, I have taken the liberty to label these as lessons. These are primarily lessons about what to avoid. ${ }^{3}$

\footnotetext{
${ }^{2}$ For the connection to recurring Díaz Alejandoesque themes in my works, see Calvo, Leiderman, and Reinhart (1993) on the importance of external factors explaining boom-bust cycles in Latin America; Kaminsky and Reinhart (1999) on financial liberalization as a driver of banking problems and external crises; Reinhart and Rogoff (2009) on the sequencing of crises and protracted nature of the recovery; and Reinhart and Reinhart (2010) on the long leverage cycles around crises.

${ }^{3}$ On the theme of past lessons for the present and the future in the Diaz Alejandro (1983) "Stories of the 1930s for the 1980s"spirit, see, for instance, Pierre Olivier Gourinchas and Maurice Obstfeld's (2012) "Stories of the Twentieth Century for the Twenty-First." Their study places emphasis on the antecedents and early warning symptoms of financial crises. Graciela Kaminsky and Alfredo Pereira’s (1996) "The
} 
Since it is the Latin American and Caribbean Economic Association who honors his memory with the Carlos Díaz Alejandro Prize, it seems appropriate to circle back and conclude the tour of his writings with the question: Is another Latin American crisis brewing?

\section{Carlos F.}

Carlos F. Díaz-Alejandro started in Yale in 1961 as an assistant professor in the department of economics immediately after completing his graduate training at the Massachusetts Institute of Technology. He took a brief detour to the University of Minnesota, but, by 1969, he returned to Yale to become the youngest full professor ever in the economics department up until that point. In 1983, he moved to Columbia University. By that time at the age of 45 , the high quality of his work had established him as a distinguished, indeed preeminent, Latin American economics scholar. His last years yielded the writings for which Carlos is now most cited in the economic literature.

Carlos died in July 1985, leaving behind not only an amazing intellectual output, but also a multitude of students, colleagues, friends and academic devotees who loved the man at least as much as his writings.

Reading Díaz Alejandro should give anyone hope that economics can be encompassing, engaging, and occasionally humorous. He addressed a broad range of topics with an open mind but was guided by a respect for the past. He emphatically cared about public policy.

Kindleberger, his professor, mentor, and friend reminds us that when Carlos went to MIT in the late 1950s, it was with the wish to put his training to good use upon his

Debt Crisis: Lessons of the 1980s for the 1990s," is another example. This paper deals primarily with the aftermath of severe crises, including an analysis of post-crises investment collapses that carries a great deal of current resonance, especially for the European post-2009 experience. 
return to his beloved Cuba. In his application for admission, he wrote more than half-acentury ago, that he was

.... hopeful that sound and dynamic economic policies could do a great deal toward improving the general standard of living in my country Cuba. This fact has weighed heavily in my decision to select Economics as my career. I would like to.... have a general knowledge in all fields of Economics and mastery of the principles governing economic development and growth, and the governmental policies which would be appropriate to facilitate them...

After receiving my Ph.D. degree, I hope to find employment in the Department of Economic Research of the Cuban National Bank. Later on, I would like to formulate, or help to formulate, the policies of that institution and those of the government... ${ }^{4}$

Notwithstanding the passage of time and the changes in the world since Carlos died, he is intellectually alive today and his work is hugely pertinent for the challenges of our time. To build that case, I illustrate that his reality-based economic analysis has aged very well indeed. Along the way, I provide a brief tour of some of his most important contributions and highlight some instances where his work has influenced other scholars in his field. Reading Díaz Alejandro is a must for students of financial crises and highly recommended for anyone interested in trade and development as well. ${ }^{5}$ His 1970 Essays on the Economic History of the Argentine Republic is a classic that continues to influence today’s leading economic historians. ${ }^{6}$

\section{Timeless Policy Relevance}

Carlos’s writings were often drew upon the lessons of history, particularly those involving serious policy mistakes, to forge practical (and often eclectic) policy advice for

\footnotetext{
${ }^{4}$ See Kindleberger (1989).

${ }^{5} \mathrm{I}$ am using the term financial crises in its most encompassing meaning. Specifically, it is meant to include, banking, currency, debt, and inflationary crises.

${ }^{6}$ See, for example, Della Paolera and Taylor's (2001) authoritative account of the famous Barings crisis of 1890.
} 
the world's “underdogs.” 7 In his day, they were called LDCs, for less-developed countries. In our more "politically correct” time, we call them emerging markets when the countries in question are middle income and developing countries when they are low income. Carlos often liked to refer to the advanced and emerging country groups as “North” and "South,” respectively.

Whatever we choose to call them, many of the policy challenges (or the mistakes, for that matter) have not changed much in the three decades since Diaz-Alejandro wrote his last papers. ${ }^{8}$ Furthermore, some of the differences between advanced and developing economies that emerged after World War II and were prevalent at the time he was writing have narrowed in recent years. The 2007-2008 financial crises in advanced economies shared many traits with emerging market crises in terms of their severity, loss of access to international capital markets (in some cases), and the sharp credit downgrades that ensued, among other features. ${ }^{9}$ On this basis, I argue that many of the insights found in his works are universal in scope.

What does Díaz Alejandro have to say about the factors that drive countries through financial and economic booms that so often end in in tears?

\footnotetext{
${ }^{7}$ See Kindelberger (1989), also see, for instance, the long list of policy recommendations in Díaz Alejandro (1984).

${ }^{8}$ At present, Greece has entered a banking holiday and has become the first advanced economy to default on its obligations to the IMF.

${ }^{9}$ For analyses of various dimensions of the similarities between advanced and emerging economies' crises patterns, see Reinhart and Rogoff (2009) and Gourinchas and Obstfeld (2012).
} 


\section{The Tour Begins: Five Lessons Why Financial Crises Happen}

Most of the quotes are taken from his most cited piece, “Goodbye Financial Repression, Hello Financial Crash.” All of the lessons highlight some form of policy failure at both micro and macro levels. We are describing a process...

“...where domestic financial intermediation flourished and then collapsed.”

While Díaz Alejandro offers these insights in the narrative of a particular crisis, Andres Velasco, his student at Columbia University at this time, formalized the core elements of the story in a model of the twin crises. In Díaz Alejandro (1985) as well as Velasco (1989), banking problems emerge first and set the stage for currency collapse. ${ }^{10}$ The proximate causes of both crises are policy inconsistencies amplified by distortions in the financial sector, as we shall see.

"Whether or not deposits are explicitly insured, the public expects governments to intervene to save most depositors from losses when financial intermediaries run into trouble. Warnings that intervention will not be forthcoming appear to be simply not believable."

Lesson 1: We have a serious domestic moral hazard problem.

The belief that officials will step in to protect people from the results of their mistakes makes them more willing to take on risk. This is the "heads you win, tails your government loses” that has often characterized official responses in 2008 and 2009 to the financial crash following the bursting of the subprime bubble. It is also applicable to numerous crises since the paper was written in the mid-1980s. Carlos also goes on to

\footnotetext{
${ }^{10}$ In Velasco (1989), there is no sovereign default on external debt. Default is avoided because it is assumed that the Central Bank's initial stock of foreign reserves is sufficient to cover all the external debts of the banking sector. Private debts become public debt at the time of the banking crisis, prompting a sudden decline in central bank reserves. However, it would be the case that if the initial level of reserves proved insufficient, then the banks and the sovereign would be simultaneously bankrupt.
} 
explain that nothing the government can say before the fact can credibly convince people that they will not be protected after the fact. After all, wounded investors are also aggravated voters.

"Foreign lenders take government announcements that it will not rescue local private creditors, especially banks, with non-guaranteed external (or domestic) liabilities even less seriously than depositors take the threat of the loss of their money."

Lesson Number 2: We have an even more serious external moral hazard problem.

Foreign investors also recognize that governments worry about continued access to world markets. So great is the worry, in fact, that officials will take over the obligations of private parties to foreigners at a time of stress. Private debt becomes a public burden. We must remind the reader at this stage that he was writing about Chile in the early 1980s, not Iceland, Ireland, Spain, the United States, among many other post2008.

"The Central banks, either because of a misguided belief that banks are like butcher shops, or because of lack of trained personnel, neglected prudential regulations over financial intermediaries."

Lesson Number 3: Central banks (and their regulatory and rating-agency colleagues) made the moral hazard problem worse.

Time and time again, the expertise of those who watch falls short of those who are watched, because of the belief in the public sector in the wisdom and discipline of markets and the compensation practices of the private sector. These supervisory failures make officials more willing to use taxpayer resources to clean up their mistakes.

To crystalize this point with an example, see Table 1 . In the years leading up to the Icelandic crisis of 2007, gross external debt almost quadrupled to about 4 times GDP 
by 2006 and current account deficit reached 26 percent of GDP (from a surplus only 4

years earlier). Throughout, sovereign credit ratings were essentially unchanged.

Table 1. Iceland: Evolution of Credit Ratings: 2002-2008

\begin{tabular}{cccccccc}
\hline \hline Year & $\begin{array}{c}\text { Current } \\
\text { account/GDP }\end{array}$ & $\begin{array}{c}\text { Gross } \\
\text { External } \\
\text { debt/GDP }\end{array}$ & $\begin{array}{c}\text { Domestic } \\
\text { credit/GDP }\end{array}$ & \multicolumn{2}{c}{$\begin{array}{c}\text { Moodys ratings on } \\
\text { long-term debt }\end{array}$} & \multicolumn{2}{c}{$\begin{array}{c}\text { S and P ratings on } \\
\text { long-term debt }\end{array}$} \\
& & & & Domestic & Foreign & Domestic & Foreign \\
\hline 2002 & 1.6 & 122.3 & 104.8 & Aaa & Aaa & AA+ & A+ \\
2006 & -25.7 & 423.9 & 304.6 & Aaa & Aaa & AA & A+ \\
2008 & -28.3 & 697.2 & 185.9 & Baa1 & Baa1 & BBB + & BBB- \\
\hline \hline
\end{tabular}

Sources: International Financial Statistics, and World Economic Outlook, International Monetary Fund, Moodys, Standard and Poors', and World Bank, Quarterly External Debt Statistics.(QEDS).

Notes: External debt is public plus private while domestic credit is exclusively private. Appendix Table A.1 provides explanations for the ratings.

"In economies characterized by intractable market and informational imperfections, conglomerates and economic groups, even as they may correct government-induced financial repression imperfections, could exacerbate others, particularly via the creation of oligopolistic power."

Lesson Number 4: Financial deregulation exacerbates the "too big to fail” problem. Indeed, the objective of every small or medium-sized institution is to become too big to fail.

At a time of stress, officials inevitably become concerned that the failure of one firm will trigger failures at many other firms. That concern is greater the larger and more interconnected is the firm. The protections afforded to such too-big-to-fail entities leads competitors to try to get big and interconnected as well. This unhappy pattern explains both the risk-taking of large, complicated financial intermediaries that helped to stoke the fires of the subprime financial crisis and the official response of widespread bailouts that followed.

"The combination of pre-announced or fixed nominal exchange rates, relatively free capital movements, and domestic and external financial systems characterized by the moral hazard and other imperfections set the stage for not only for significant microeconomic misallocation of credit, but also for macroeconomic instability, including the explosive growth of external debt." 
Lesson Number 5: Inconsistent incentives in the financial sector trigger macroeconomic crises.

The commentary in its full form applies to the euro area (for countries within the euro-zone). If the fixed nominal exchange rate clause is dropped, it also becomes applicable to the United Kingdom and the United States (as well as Japan pre-1992 crisis, among a long list of others.

Carlos also went on to observe that, despite producing higher real interest rates, financial liberalization did not deliver higher domestic savings, as advertised in the academic and policy literature of the time-in effect, savings rate declined markedly. ${ }^{11}$ For that matter, he goes on to say that there was little to suggest that investment had become more productive as a result of financial liberalization. He observed that much of the post-liberalization borrowing had the worrisome features that it was skewed toward shorter maturities and foreign currencies. These features of the debts left countries vulnerable to the vagaries of volatile financial markets when the time came to roll over debts arrived.

As early as the 1960s (his dissertation), Carlos identifies the problem (particularly acute in developing countries) of borrowing in someone else’ currency, a phenomenon now widely known as liability dollarization. ${ }^{12}$ This borrowing pattern is further complicated by the fact that the (foreign) currency that the debt is denominated in is usually a hard currency (at least in relation to the home one), so large and or frequent

\footnotetext{
${ }^{11}$ As an example, in the United States, the personal saving rate was about 12 percent in 1981, before the last wave of financial liberalization; it was at a historic low of less than two percent when the financial 2007-2008 crisis began.

${ }^{12}$ Díaz Alejandro(1965).
} 
devaluations or depreciations of the domestic currency unequivocally worsen balance sheets. $^{13}$

\section{The Tour Continues: The Anatomy of Crises}

Skimming the surface of his contributions here should be sufficient to entice the interested reader to further investigate his insightful writings. Fear not to tread, because these papers set an admirable benchmark of accessibility.

As a reminder, Díaz Alejandro (1985) was discussing Chile in the early 1980s; the relevance is of recent vintage. The story begins with liberalization, reforms, and innovations in the financial industry

“... aimed at generally seeking to free domestic capital markets from alleged government-induced distortions,...

(As the reader is fully aware by now, the story ends badly.)

...yielded domestic financial sectors characterized by widespread bankruptcies, massive government interventions... and low domestic savings.”

That is, it is a story of two parts, before and after.

\section{Good-bye financial repression...}

The historical context of Díaz Alejandro (1985) involved the so-called “tablitas” that helped define the inflation stabilization programs of the Southern Cone (Argentina, Chile, and Uruguay) in the late 1970s and early 1980s. ${ }^{14}$ All three countries had been battling (unsuccessfully) high and chronic inflation. The tablitas were pre-announced

\footnotetext{
${ }^{13}$ I wish to thank Guillermo Calvo for pointing out to me this early reference to liability dollarization in Carlo's work. As it turns out, Calvo also informed me that it was Maury Obstfeld who found the original reference and pointed it out to him. A fact Obstfeld subsequently confirmed. See Calvo, Izquierdo, and Mejia (2008) for compelling empirical evidence on the quantitative importance of these balance sheet effects.

${ }^{14}$ See Díaz Alejandro (1981) and Vegh (1989).
} 
schedules for the path of the nominal exchange rate (broadly, a crawling peg system with a declining rate of crawl). Not quite a peg, but nonetheless the nominal exchange rate was tied to the US dollar in the expectation that ultimately their inflation rates would converge to that of the United States.

There are parallels with the European experience prior to the introduction of the euro. The inflation rates in the Southern Cone were much higher than the ones recorded in periphery Europe, but the approach to disinflation where the periphery's exchange rate shadowed a lower-inflation anchor currency (the DM) with the aim of achieving convergence is essentially the same.

Fiscal conditions differed markedly across the Southern Cone during this period. It is generally accepted that the fiscal positions of Argentina and Uruguay were significantly weaker than that of Chile. Domestic financial liberalization was accompanied by a meaningful reduction in capital controls (external liberalization), so Carlos asks us to consider a country that had liberalized its domestic financial sector and was fully integrated into world capital markets. Describing Chile, he observes:

"The recorded public sector deficit was nonexistent, miniscule, or moderate; the declining importance of ostensible public debt in the national balance sheet was celebrated by some observers."

To illustrate that the analysis has aged well, in what follows, Iceland and Ireland step in to take over the role played in an earlier era by Chile (Spain could be added to this list). Greece' considerably weaker fiscal conditions at the outset of the crisis were closer to Argentina's predicament in the early 1980s but with markedly higher levels of domestic and external public. ${ }^{15}$ As Figure 1 illustrates for Iceland and Ireland, public

\footnotetext{
${ }^{15}$ Relative to Argentina, Greece also had a markedly higher level of private debt-a potential contingent liability of the public sector, as we shall see.
} 
debt to GDP hovered around 20-30 percent at the outset of the crisis, which can be safely considered relatively low by most historical or cross-sectional standards.

Figure 1. Iceland and Ireland: Government Debt as a Percent of GDP: 1925-2015

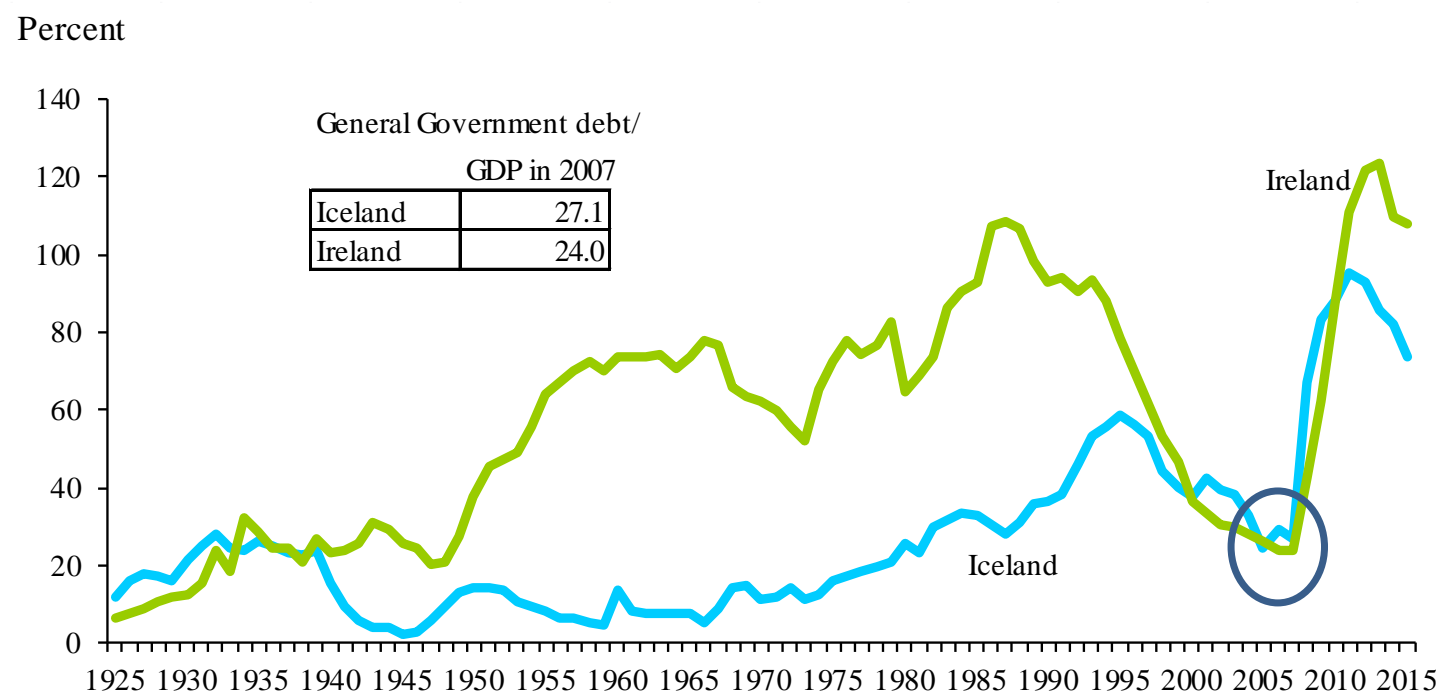

Sources: International Monetary Fund, World Economic Outlook, Reinhart and Rogoff (2009).

The private sector was a different matter. Their spending persistently exceeded their income, giving rise to large current account deficits. The current account deficit was financed by large and persistent capital inflows, which is a different way of saying that the domestic largesse was supported by borrowing heavily from the rest of the world. Figure 2, shows gross external debt (public and private) for Iceland and Ireland. External debt-to-GDP ratio rose by more than 400 percentage points in both countries the five years before the crisis; possibly establishing an all-time pre-crisis record for either advanced or emerging economies. ${ }^{16}$

\footnotetext{
${ }^{16}$ The scale of external debt recorded for Iceland, Ireland, and other European countries is a multiple of the highest levels reached around emerging market crises.
} 
This abundance of foreign capital made it easy for domestic banks to lend liberally to businesses and households (Figure 3). ${ }^{17}$ During the credit boom, real estate and equity prices soared along with the debts. Growth seemed inevitable.

However, as Carlos explains, the pity of the boom is that

"little effort was spent on investigating the credentials of new entrants to the ever-growing pool of lenders and borrowers...practically no inspection or supervision of bank portfolios existed...One may conjecture, however, that most depositors felt fully insured and foreign lenders felt that their loans to the private sector were guaranteed by the State."

Figure 2. Iceland and Ireland: Total (public plus private) Gross External Debt as a Percent of GDP, 1970-2014

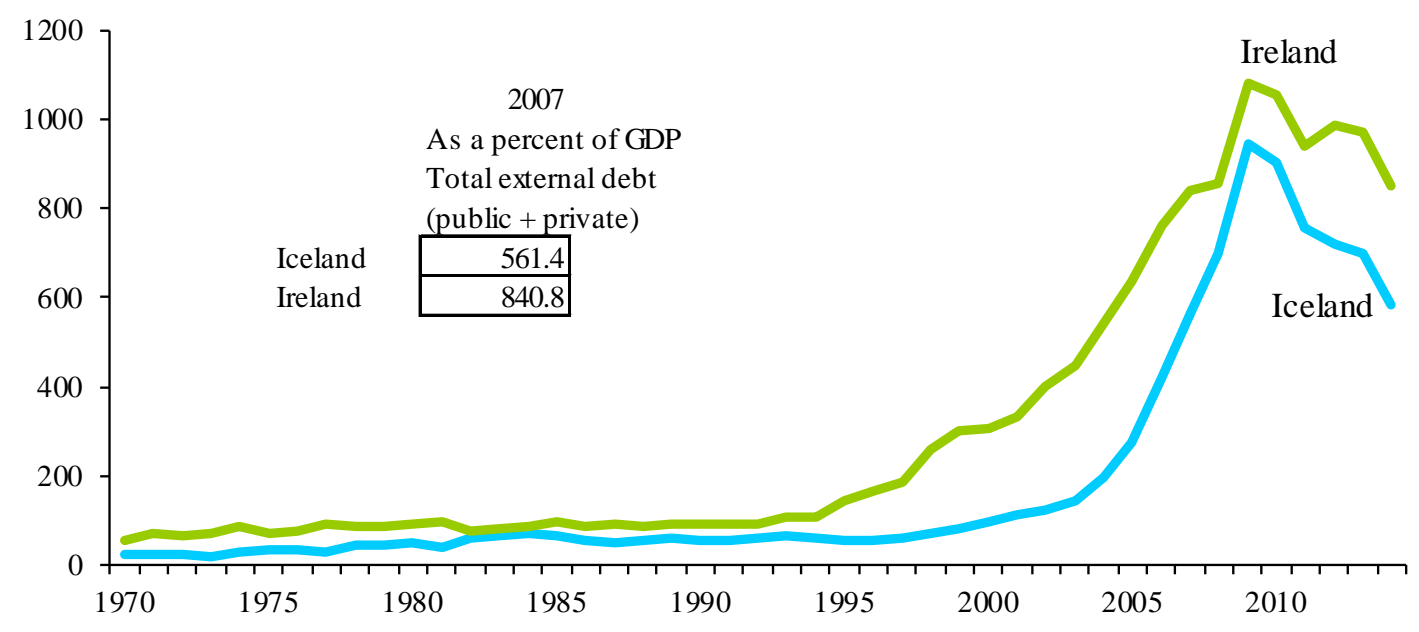

Sources: International Monetary Fund, International Financial Statistics Lane and Milesi Ferreti, World Bank, Quarterly External Debt Statistics.(QEDS).

\footnotetext{
${ }^{17}$ The strong connection between external capital flow and domestic credit cycles is a recurring theme dating back to Carlos' 1970 economic history of Argentina. Mendoza and Terrones (2012) generalize and reaffirm this connection for a large panel of advanced and emerging economies.
} 
Figure 3. Iceland and Ireland: Private Domestic Credit as a Percent of GDP Percent

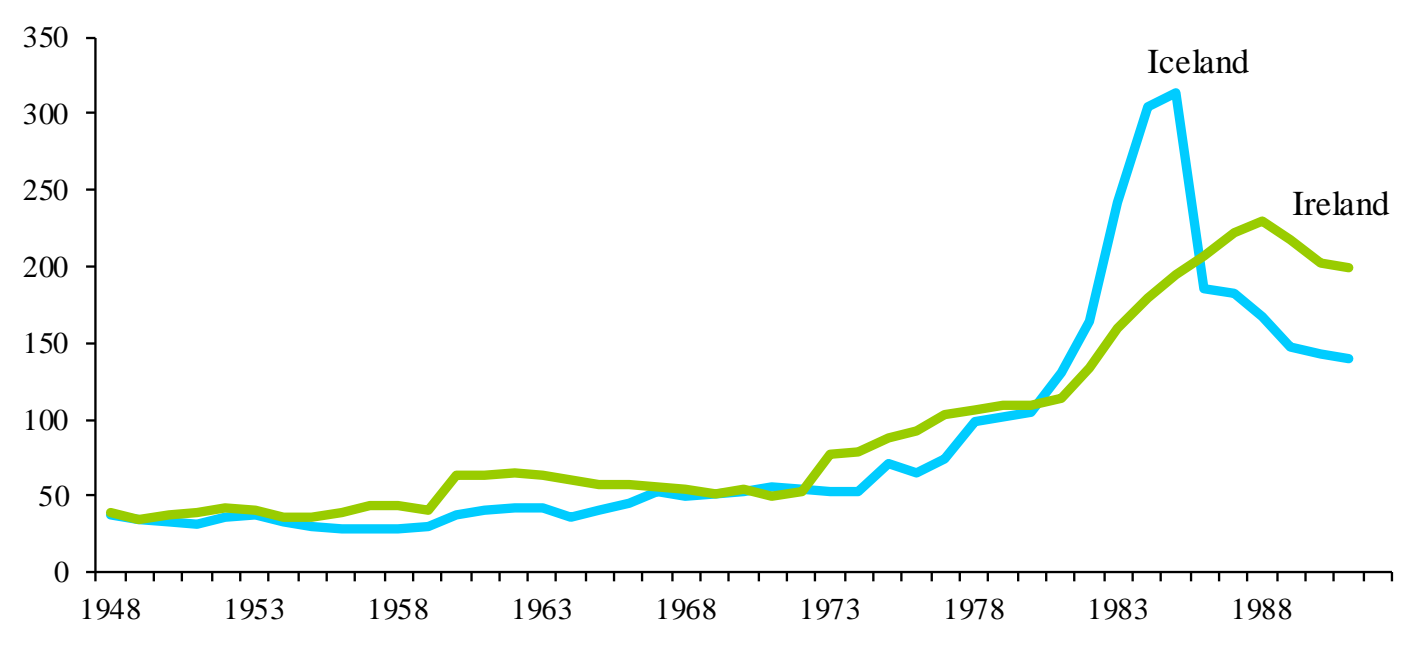

Sources: International Monetary Fund, International Financial Statistics

These passages capture much of the essence of Diaz-Alejandro's analysis of “the unintended consequences of financial liberalization in Latin America during the late 1970s.” Unfettered laissez-faire banking engaged in borrowing from the rest of the world at one end to support indiscriminate domestic lending at the other end.

If Carlos' description of events has a modern-day resonance, it is because variants of this story aptly describe the evolving state of affairs in the years before many, if not most of the worst financial crises since his article was published in the mid-1980s.

In effect, the surge in asset prices, notably housing prices, and borrowing of the advanced economies in the "bonanza" decade prior to the crisis dwarfs the size of the lending booms that Carlos was describing for emerging Latin America. As Table 2 makes plain, real (inflation-adjusted) housing prices more than doubled in most cases during 1997-2007. The boom in asset prices, spending, and the size of the financial industry was fueled by a surge in leverage as illustrated in Figures 2-3 and Table 2, which shows the cumulative increase in debts from 1997 to 2007. 
Apart from housing or equity prices, another feature of the stop-go cycle that Díaz Alejandro $(1970,1981,1983$, and 1985) stressed, is that the boom as well as the eventual fiasco that followed are importantly connected to the relative price of traded and nontraded goods, or the real exchange rate. For instance, Diaz Alejandro’s (1981) discussion of the inflation stabilization programs of the Southern Cone countries highlights the key role played by “currency overvaluation” (or significant real exchange rate appreciations) in explaining the widening current account deficits and setting the stage for the banking and currency crises that ushered in the debt crisis.

His work is intertwined with a rich and influential literature on this topic. Guillermo Calvo's (1986) and (1989) frameworks elegantly connect the dynamics of the real exchange rate and the boom-bust cycle to lack of credibility (in the sense that it is not expected that the reforms will stick). Some of Rudiger Dornbusch's writings on this topic are seminal. ${ }^{18}$ With a wealth of data on the developing country experience, Sebastian Edward's (1989) book on the subject addresses the eternal question of measuring misalignments. More recently, Kaminsky and Reinhart (1999) and Gourinchas and Obstfeld (2012) arrive at a similar conclusion on the key role of the real exchange rate in connection with the recurrent boom-bust cycles. Both studies conclude that currency overvaluations are among the top leading indicators of financial crises (notwithstanding different methodological approaches and samples). ${ }^{19}$ The richness of the policy debate on what to do about the "overvaluation problem" in the context of Mexico in the 1990s was famously manifest in Dornbusch and Werner (1994) and Calvo's discussion of that paper.

\footnotetext{
${ }^{18}$ See Dornbush (1986) and references therein.

${ }^{19}$ See Frankel and Saravelos (2012) for a discussion of the role of "overvaluations" in the 2008-2009 crises and a comprehensive survey of the literature.
} 
A related discussion is alive and well in the context of periphery Europe's competitiveness challenges.

Table 2. Selected Indicators: Iceland and Ireland, Changes 1997 to 2007

\begin{tabular}{rcccc}
\hline \hline Country & $\begin{array}{c}\text { real house } \\
\text { prices } \\
\text { (percent) }\end{array}$ & $\begin{array}{c}\text { domestic } \\
\text { private } \\
\text { debt/GDP }\end{array}$ & $\begin{array}{c}\text { gross external } \\
\text { debt/GDP }\end{array}$ & $\begin{array}{c}\text { Deterioration in the } \\
\text { current account } \\
\text { /GDP }\end{array}$ \\
\hline Iceland & 66.9 & 243.3 & 501.0 & 13.9 \\
Ireland & 114.8 & 107.6 & 654.9 & 8.7 \\
\hline \hline
\end{tabular}

Notes: The debt buildups and housing price increases are calculated over 1997-2007.

\section{Hello Financial Crash...}

As leverage mounted, the precariousness of the balance sheet of financial institutions became evident and failures began to emerge. In what follows, we ask the reader to fill in their country and year of choice in the description that Carlos offers us of the unfolding crisis.

"The Central Bank undertook rescue operations of banks and other financial intermediaries... to avoid a breakdown of the financial system... The opaqueness of the intervention procedures, and of the announced processes to settle the tangled web of inter-company and bank debts ..." 
Figure 4. Iceland: Insolvencies of Enterprises, 1990-2014

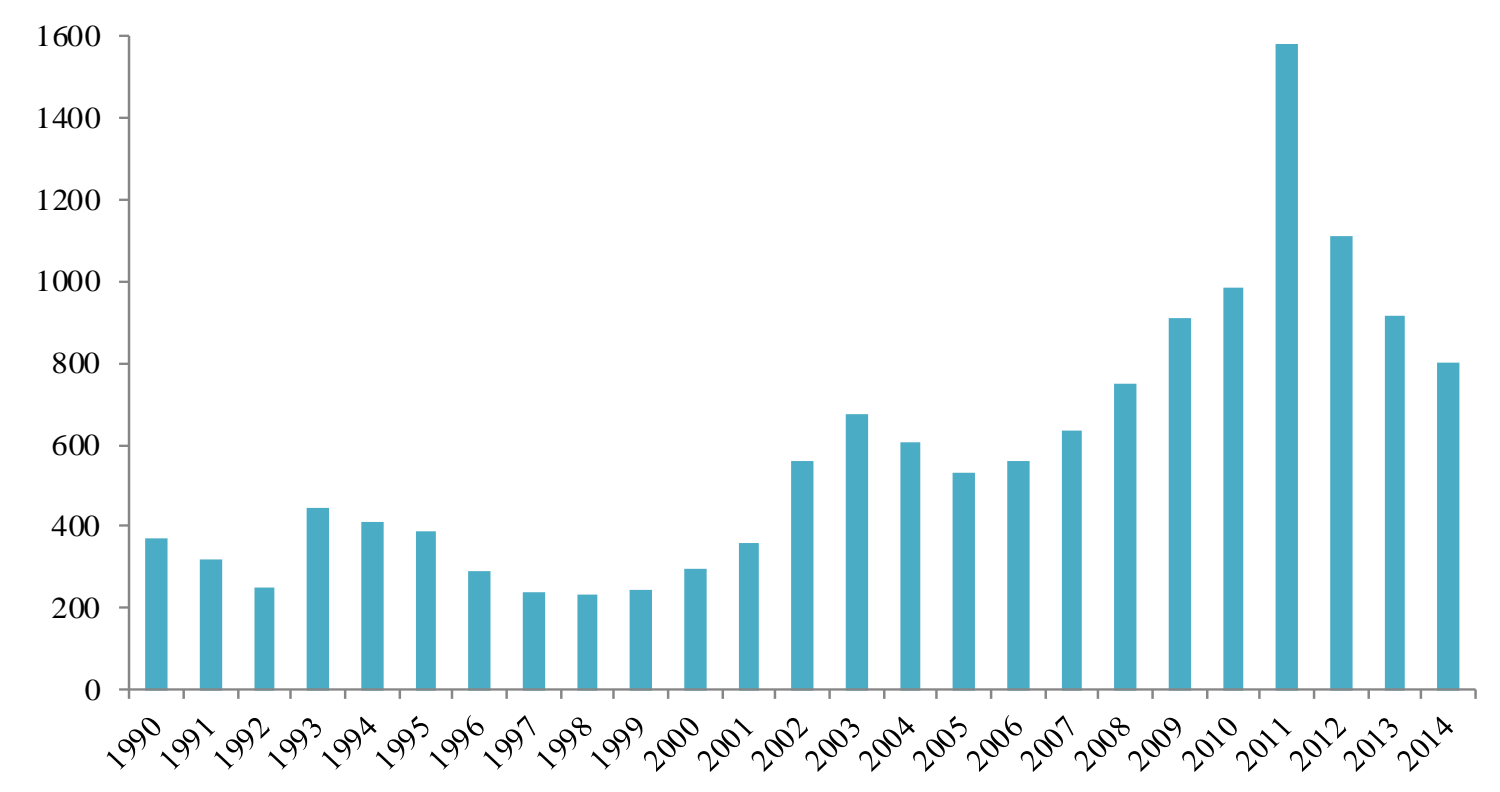

Source: Statistics Iceland

True to the script, Figure 4 plots the number of insolvencies for Iceland over 1990 to 2014; the impact of the crisis needs little explanation. Furthermore, as Figure 1 shows, public debt (as a percent of GDP) in Iceland and Ireland quickly climbed from around 30 percent to over 100 percent. This is importantly attributable to the fact that private debts before the crisis quickly became public debts during the crisis (as banks were rescued). The governments, losing access to private international capital markets, began to rely more heavily on official creditors (including the IMF) and the central bank.

The legacy of the severe financial crises Carlos F. Diaz-Alejandro wrote about early in the 1980s eventually became known as the "lost decade" for Latin America. As early as 1982, he had pointedly characterized the 1980s as a decade of "Hangover, Penance, and Purges?" Few observers had pinned the diagnosis for developing countries of a long decade filled with lower capital inflows, tough borrowing conditions, debt 
problems, and diminished economic growth so accurately or so early. ${ }^{20}$ Speculating on the crises aftermath, he (and co-author Bacha) wrote:

"The growth rates of gross national products of major semi industrialized borrowers could decline, even relative to those of 1973-1980, while pressure to expand exports and restrain imports will continue..."

“The outlook for the poorest LDCs remains somber and their need for concessional finance great."

Apart from his prescient concerns about the growth prospects of highly indebted countries after the crisis, he was also worried about how the downward adjustment in expenditures was achieved. Specifically, Diaz-Alejandro was concerned with the thenemerging evidence that the brunt of the adjustment was coming from investment rather than consumption and that the violent reduction in investment would not only impair present but future growth.

"The worst aspect of Latin American macroeconomic performance during 1982 and 1983 is not to be found so much in the contraction of absorption (total expenditures) and output, bad as those were, particularly in per capita terms; the worst was the violent reduction in investment, which impaired not only present but future growth, even granting the existence of substantial excess capacity" 21

For the largest eight Latin American economies, real per capita GDP growth averaged 2.6 percent per annum from 1950 to 1980; in the decade that followed, annual per capita GDP growth averaged -0.7 percent. Not until the Brady debt restructuring plan of 1989 did these countries resolve the debt overhang left over from the financial crisis nearly a decade earlier.

\footnotetext{
${ }^{20}$ Bacha and Diaz Alejandro (1982).

${ }^{21}$ Díaz Alejandro (1983). Kaminsky and Pereira (1996), who compare the Asian and Latin American experience, provide empirical backing to Carlo's hunch that this kind of adjustment would inflict long-term damage on Latin America.
} 
If the antecedents of severe financial crises that Carlos described ring true in summarizing the run-up to the 2007-2008 crisis, so did his characterization of slow growth, low investment, and debt overhang in their aftermath. As Reinhart and Reinhart (2010) document, a decade of lower growth in the wake of a severe financial crisis is not unique to the emerging market crises of the early 1980s. It is also a feature of the post crisis experience in advanced economies, even when there is no loss in capital market access or distinct decline in the terms of trade. Figure 5, from that paper, which plots the frequency distributions of real per capita GDP growth of the decades before and after five systemic post-WWII crises in advanced economies, illustrates this point.

Apart from a worsening of the external environment for developing countries in the early 1980s, the penance-and-purges era of low growth Bacha and Diaz Alejandro (1982) anticipated may also be connected to the more general multi-year leverage or debt cycle surrounding these crises. In that paper, which is an encompassing discussion of international capital market developments in the 1970s (with Carlos' usual dose of historical examples), the role of intermediation and banks is connected to economic activity and developments in the current account (what would be later referred to as global imbalances). ${ }^{22}$ Figure 6, also from Reinhart and Reinhart (2010), highlights how, for both advanced and emerging market financial crises, a full private sector debt cycle involves both significant debt build-ups ahead of the crisis (median increase in domestic credit/GDP is almost 40 percent) and a comparable degree of deleveraging afterwards. The deleveraging phase provides significant headwinds to growth. As appendix Table A.1 documents, the full cycle can last between one and two decades.

\footnotetext{
${ }^{22}$ There is much discussion and documentation of shifts in current account balances across time and broad country groupings.
} 
Figure 5. Real Per Capita GDP Growth in the Decade Before and the Decade After Severe Financial Crises: Post-WWII, Advanced Economies

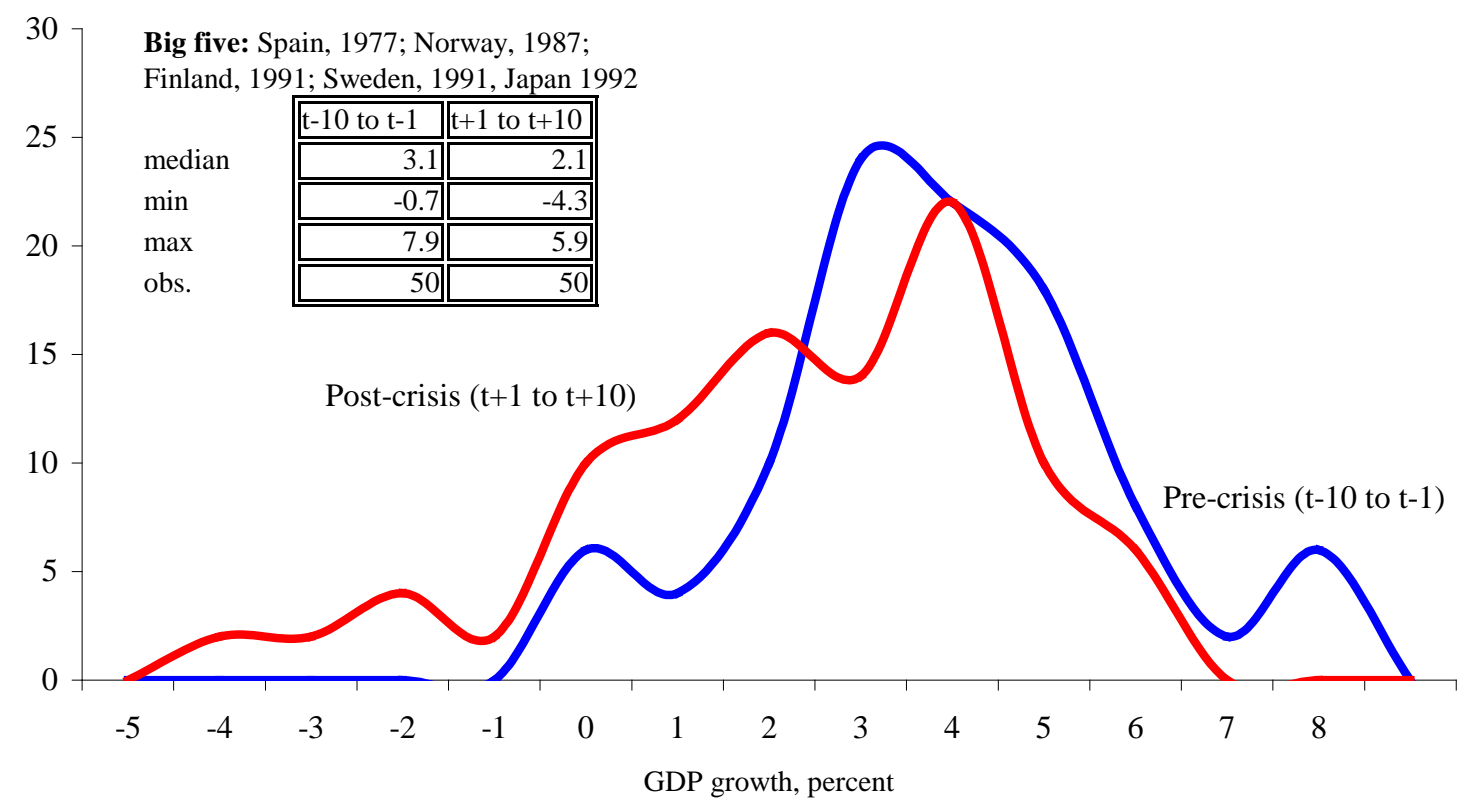

Source: Reinhart and Reinhart (2010). 
Figure 6. Domestic Banking Credit/GDP Twenty-one Years Around Severe Financial Crises: Amplitude of Boom-Bust Credit Cycles in fifteen Post WWII Episodes

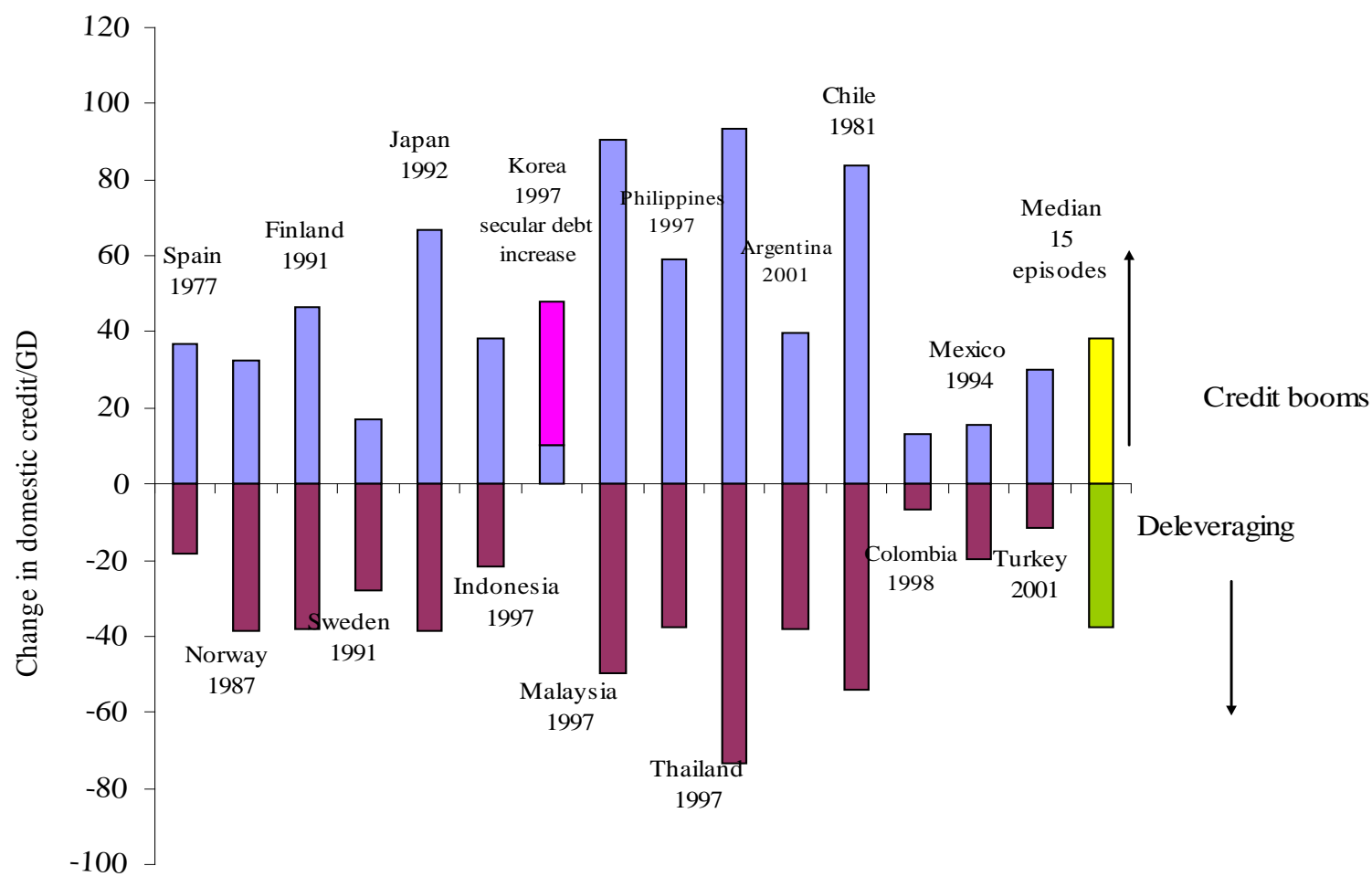

Sources: Reinhart and Reinhart (2010) and Table A.1 from the same source.

Notes: The magnitude of credit booms shown correspond to the difference between the maximum domestic bank credit-GDP ratio around the crisis and the pre-crisis low for the ratio during the 10year window preceding the crisis. Similarly the extent of deleveraging is calculated as the minimum credit/GDP ratio reached during the 10-year window after the crisis and the maximum ratio reached around the crisis. The specific dates and magnitudes for each episode are listed in Table 3.

For Korea, there is an uninterrupted secular rise in domestic bank credit-to-GDP during 1987-2007 (the 10-year window around the crisis). Post-crisis deleveraging appears to be confined to external debts (see Reinhart, 2010).

As Reinhart and Rogoff (2014) document for the 100 worst financial crises since 1860, not every deep financial crisis leads to a lost decade, as was the case for Latin America in the 1980s and for a large number of countries on all regions in the 1930s. ${ }^{23}$

\footnotetext{
23 The Great Depression of the 1930s was also a recurring topic or point of reference in Diaz Alejandro's works.
} 
They find that the average number of years to recover the pre-crisis peak in per capita GDP is about 8 years (the median is $61 / 2$ years).

Table 3 updates the Reinhart and Rogoff (2014) exercise with the latest projections from the International Monetary Fund's World Economic Outlook, as of April 2015, of real per capita GDP, which currently extend to 2020 . The $6^{\text {th }}$ column in the table shows, in particular, the number of years that it is estimated that it will take to get back to the pre-crisis peak in per capita GDP. In the 2007-2008 wave of crises, 7 or 8 years have elapsed since the start of the crisis (depending on the country).

Table 3. Real Per Capita GDP, Crises, and Recovery: 2007-2021 12 Systemic banking crises, 2007-2008

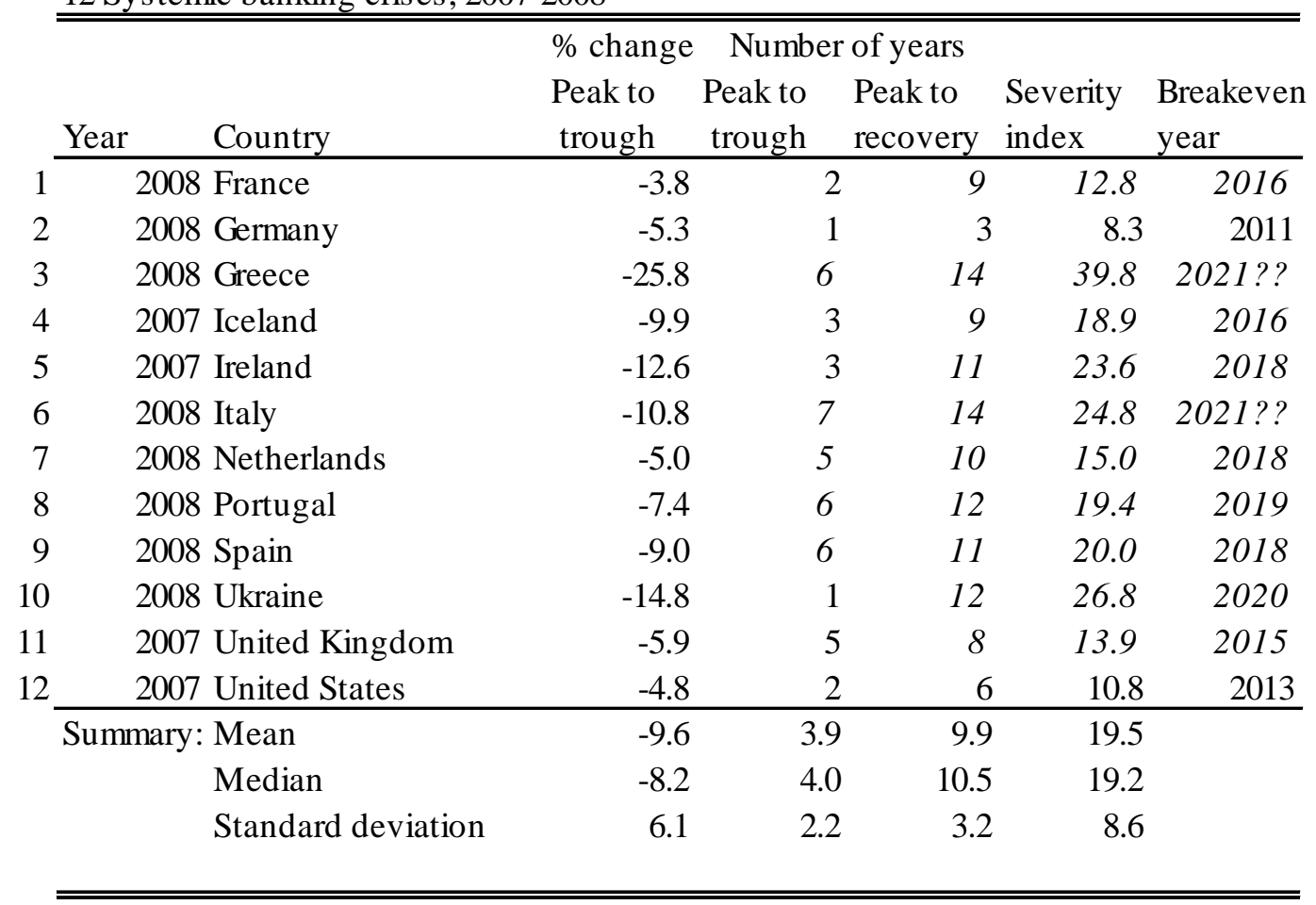

Note: The italics denote any calculations in which IMF estimates for 2015-2020 are used. Sources: Reinhart and Rogoff (2014) updated with World Economic Outlook, April 2015.

If the projections for the remaining years through 2020 are approximately correct, Greece and Italy will not recover their pre-crisis per capita output until beyond 2020, 
placing these episodes among the most protracted since the mid- $19^{\text {th }}$ century. That is, the average may come closer to 10 years, producing another crop of lost decades.

In the lost decade that Carlos was warning about, the dismal performance of Latin American economies after the debt crisis of 1981-82, the ratio of investment to GDP fell more than 5 percentage points, on average, from 1981 to 1990 . The closing of access to foreign funding, the undermining of domestic financial institutions, and the crowding out of the private sector from large government budget deficits all work to restrain capital formation, contributing to the slower growth of output. These mechanisms, as Table 4 suggests, apparently work in the North as well as the South and across exchange rate regime. The share of investment to nominal GDP of Iceland (a currency floater) and Ireland (in a currency union) has fallen about 9 percent since their banking debacles.

.Table 4. Investment to GDP Ratios: Iceland and Ireland, 2000-2015

\begin{tabular}{ccccc}
\hline \hline Country & $\begin{array}{c}\text { 2000-2007 } \\
\text { average }\end{array}$ & $\begin{array}{c}\text { 2008-2015 } \\
\text { average }\end{array}$ & Change & 2015 \\
\hline Iceland & 26.1 & 16.8 & -9.3 & 17.1 \\
Ireland & 26.6 & 17.6 & -9.1 & 18.4 \\
\hline \hline
\end{tabular}

Source: International Monetary Fund, World Economic Outlook

\section{Advanced Economies’ Debt: I Don't Think we are in Kansas Anymore}

In his commentary on Diaz-Alejandro’s (1984) paper, “Latin American Debt: I

Don’t Think We are in Kansas Anymore”, Jeffrey Sachs begins by reminding the audience and readers that the original Wizard of Oz by L. Frank Baum is itself partly an economic parable. The Wicked Witch of the East represents Eastern capitalists who dehumanize kindly laborers like the Tin Woodman. ${ }^{24}$ The word Oz is probably

\footnotetext{
${ }^{24}$ See. Littlefield (1964).
} 
constructed by one-letter transposition of NY, the home of the predatory capitalists.

President McKinley at that time (and the International Monetary Fund today) is cast as the wizard.

The new and jarring landscape Diaz Alejandro presciently predicted was one of government budget deficits and enlarged debts. Much of deterioration traces back to the process of cleaning up the balance sheets of countless financial firms and often taking on existing or newly-toxic private debts. ${ }^{25}$ What was evident to Carlos midstream is what we are now living with. From 2007 to 2015, government public debt-to-GDP ratios for the advanced economies have risen by more than 30 percent (Figure 7), with the greatest increases recorded in countries that had major financial crises. This is the largest peacetime increase recorded.

Beginning in 2010, almost all Fannie Mae and Freddie Mac mortgage pools were consolidated and explicitly included in the debt of U.S. government enterprises, raising the public debt-to-GDP ratio by about 25 percentage points in the first quarter alone. The expectations of foreign private investors and central banks in Asia and elsewhere in the world and that had bought these U.S. "private” assets before the crisis reckoning on such a government guarantee have been fully vindicated.

"Thus, ex post it turned out that the public sector...had been accumulating an explosive amount of contingent liabilities to both foreign and domestic agents, who held deposits in, or made loans to the rickety domestic financial sector."

Carlos referred to this hidden public debt as a potential time bomb—an expression that would be aptly used again a quarter of a century later to describe the aftermath of the

\footnotetext{
${ }^{25}$ Reinhart and Rogoff (2009) also document the significant declines in government revenues associated with the post-crisis recessions.
} 
2007-2008 crisis. $^{26}$ This blurring of the line separating public and private debt and the resulting implication that a debt management strategy for the private debts is also needed to avoid the crisis is recognized by some prominent policy makers. See Maurice Obstfeld's (2014) take on Stanley Fisher's Robbins Lectures, delivered at the LSE late in 2001.

Figure 7. Public debt as a percent of GDP: Advanced Economies, 1900-2015

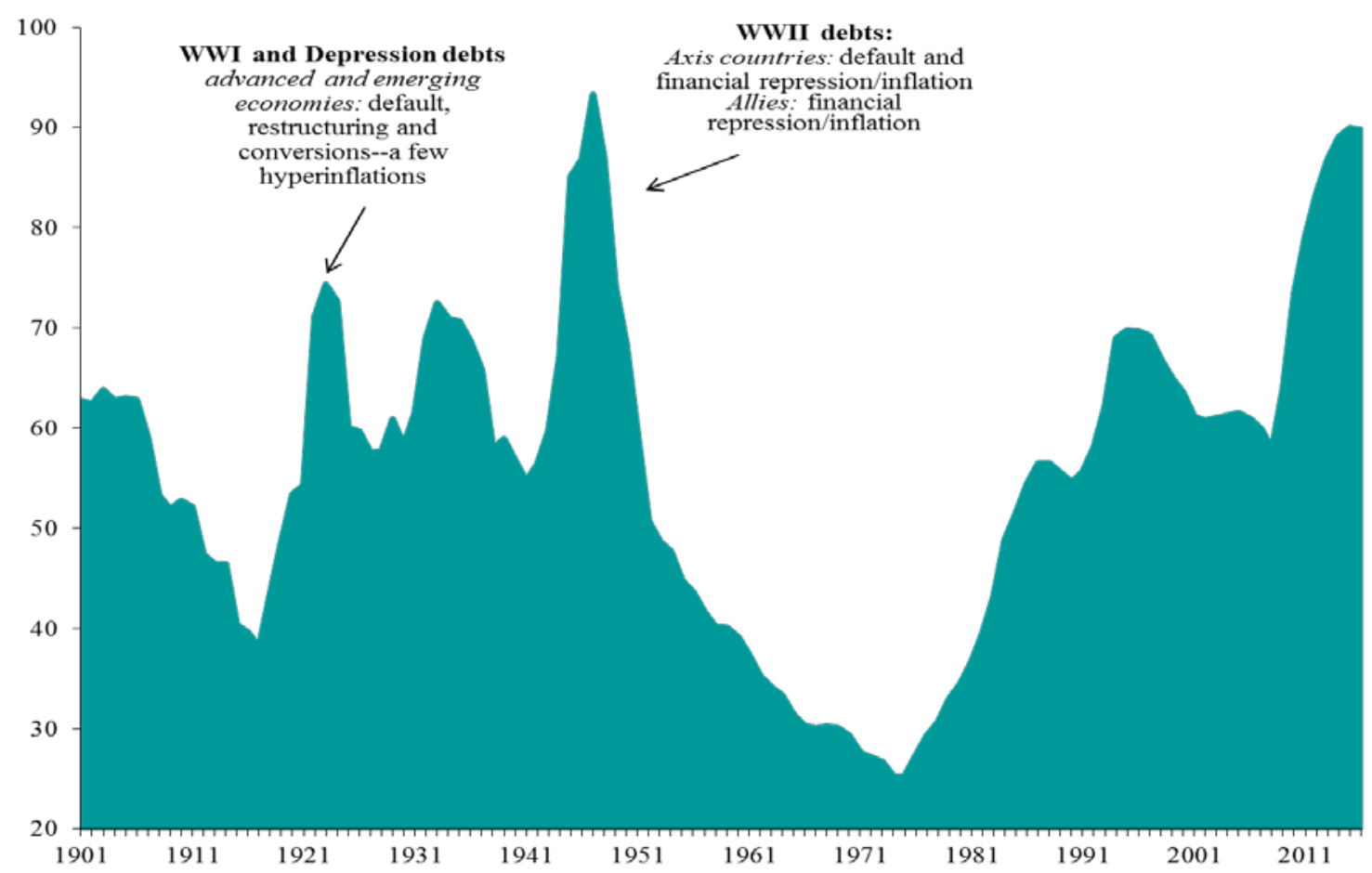

Sources: International Monetary Fund, World Economic Outlook, Reinhart and Rogoff (2009).

\section{Reflections (mostly on policy)}

It is not my aim here to draw overly simplified conclusions from Carlos’ substantial body of work but rather to remind that, in keeping with his graduate school application, Carlos was eminently practical in drawing out policy implications of his analytic assessment. Three issues seem especially pertinent for our time.

\footnotetext{
${ }^{26}$ Fisher (2010).
} 
That he viewed tackling moral hazard, too big to fail, and supervisory lapses as essential to reducing vulnerability to financial crises follows from the preceding discussion and is reiterated below. His skepticism about the ability of officials to regulate and the eagerness of investors to assume they are protected made Diaz-Alejandro suspicious about the benefits unfettered international capital mobility. ${ }^{27}$

Large capital outflows, in most cases encouraged by unconditional currency convertibility, provided a particularly explosive environment for the interaction of external shocks and imperfect policies $^{28}$

His concerns were not exclusively about finance, but also about the composition of foreign capital...

“... this paper reconsiders the implications of an inflow of capital from abroad. When the host country continues to import the capital-intensive good while remaining incompletely specialized, the analysis shows that the capital inflow must reduce host-country welfare, assuming that the foreign capital receives the full (untaxed) value of its marginal product." 29

Given his diagnosis, he was led to the conclusion that much more needed to be done with regulation, whether implemented domestically or internationally.

"Moral-hazard considerations on both sides of the market, or expectations of bailouts, reinforce the case for home-country supervision of international financial flows; if home countries do not undertake that supervision, others will do it for them."

Furthermore, Carlos’ work highlights that large capital inflows from abroad generate policy dilemmas for exchange rate policies where there are no silver bullets. Large capital inflows and appreciating currencies tend to go hand in hand. Currency appreciations have the appeal of making foreign debts easier to repay and reduce inflationary pressures (as imports become cheaper); currency appreciation, however, also

\footnotetext{
${ }^{27}$ The reference is Diaz Alejandro and Helleiner (1982).

${ }^{28}$ Diaz Alejandro (1984).

${ }^{29}$ See Brecher and Diaz-Alejandro, (1977).
} 
makes domestic goods less competitive in world markets, hitting the export industry and worsening trade balances. As Carlos was leery of sharp and rapid appreciations (factors he associated with a higher vulnerability to financial crises), this might suggest that he would lend a sympathetic ear to the efforts of numerous emerging markets (not to mention, Switzerland) to lean against the wind of an abruptly appreciating currency. This latter statement is, of course, pure conjecture.

On rescheduling private and public debts, Carlos appears to have favored an eclectic approach. In his paper with Bacha (1982), they conclude:

"Attempts to lay down universal and explicit rules for rescheduling debt, such as requiring an IMF presence in all circumstances, appear misguided under present conditions."

Around the same time, in his 1984 Brookings paper, he recommended a modest package of systemic reforms. Specifically, on the IMF:

"Expand IMF resources (which could be borrowed) so that at least the potential for sensible stabilization programs would exist."

“Despite misgivings about past and present IMF policies and lending practices, it could be argued that is was better to have an imperfect IMF than no IMF at all. Yet it is debatable that a role acceptable in a crisis should become a permanent IMF responsibility. The international equivalent to "Bankruptcy judges" found in the United States and other industrial countries remains to be created. The IMF, being itself a lender and a borrower, even if in a unique nonprofit fashion, would not be institutionally suited for the role of bankruptcy judge..."30

For the economies that are recently in the process of recovering from a severe financial crisis, Carlos work stressed that recovery from a debt overhang was a difficult and often lengthy process characterized by subpar growth. The subject of debt-overhangs straddled his analyses of the 1980s, the Great Depression of the 1930s, as well as several

\footnotetext{
${ }^{30}$ Diaz-Alejandro, Cooper, and Dornbusch, (1983).
} 
earlier crisis episodes. My interpretation of his recommendations in several papers is that an eclectic approach toward the restructuring of public and or private debts that was tailored to the particular circumstance and avoided the outright defaults so prevalent in the 1930s, should be an integral part of the solution to the debt overhang problem.

For those countries in the feast-phase of the cycle, he very clearly cautions that any buildup in private debts is to be viewed as the contingent liabilities of the government. Benign neglect towards private debts (domestic and external), in Carlos' own words, is a policy best described as a time bomb.

\section{Latin America After the Bonanza}

Repeated cycles of prosperity and depression, importantly driven by global factors that are exogenous to open or semi-open economies, were a recurring theme in Carlos Diaz Alejandro’s work. ${ }^{31}$ He was drawn to this research because of his focus on the economic performance of Latin America, but these cycles are alive elsewhere.

The United States and some of the economies in Europe are recovering, albeit rather slowly, from the worst collective financial catastrophe since the 1930s. Emerging markets fared relatively well during the maelstrom of 2008. The fact that the developing world prospered during the deep crisis in the advanced economies and its' long aftermath is perhaps most surprising for historically crisis-prone Latin America. ${ }^{32}$ Some observers attributed this resilience to the fact that many emerging markets (emerging Eastern Europe exempted) had, by both current comparisons and historic standards, relatively low levels of external public and private debts. So, even when buffeted by a sharp decline in

\footnotetext{
${ }^{31}$ See Díaz Alejandro (1970, 1975, 1983, among others).

32 This resilience is a sharp contrast to the 1930s, where emerging market economies collapsed as financial crises swept the Northern economies, (see Diaz Alejandro,1983).
} 
their exports, the abrupt loss of external financing, and declining economic growth at the height of the "global phase" of the crisis, the solvency of the governments or the general ability of the private sector to meet its immediate debt obligations was not called into question.

After the crisis, the coupling of poor growth and low interest rates in the North set into motion the usual stampede of international investors into the more rapidly-growing South in their eternal quest for high yields. ${ }^{33}$ Capital inflows to Latin America surged. For primary commodity exporters, booming world prices added to their luster (Figure 8). Through 2013, emerging markets were in the feast-phase of the old feast-and-famine cycle Carlos so carefully described. It is at this juncture of the cycle that investors and policy makers have often been deceived into thinking that this time is different. ${ }^{34}$

The notion that foreign capital pours in to reward virtuous policy and reforms has often proved too tempting to resist. Nor is this phenomenon or popular delusion (most prominent when things are going well) alien to the wealthier economies. Indeed, we often heard that very same this time is different tune applied to describe the "eurotransformations” of Greece, Ireland, Portugal, and Spain during the pre-crisis boom.

\footnotetext{
${ }^{33}$ Notably absent from international capital markets this time around were Argentina and Venezuela.

${ }^{34}$ See Reinhart and Rogoff (2009).
} 
Figure 8. Real Commodity Prices: 1854-2015

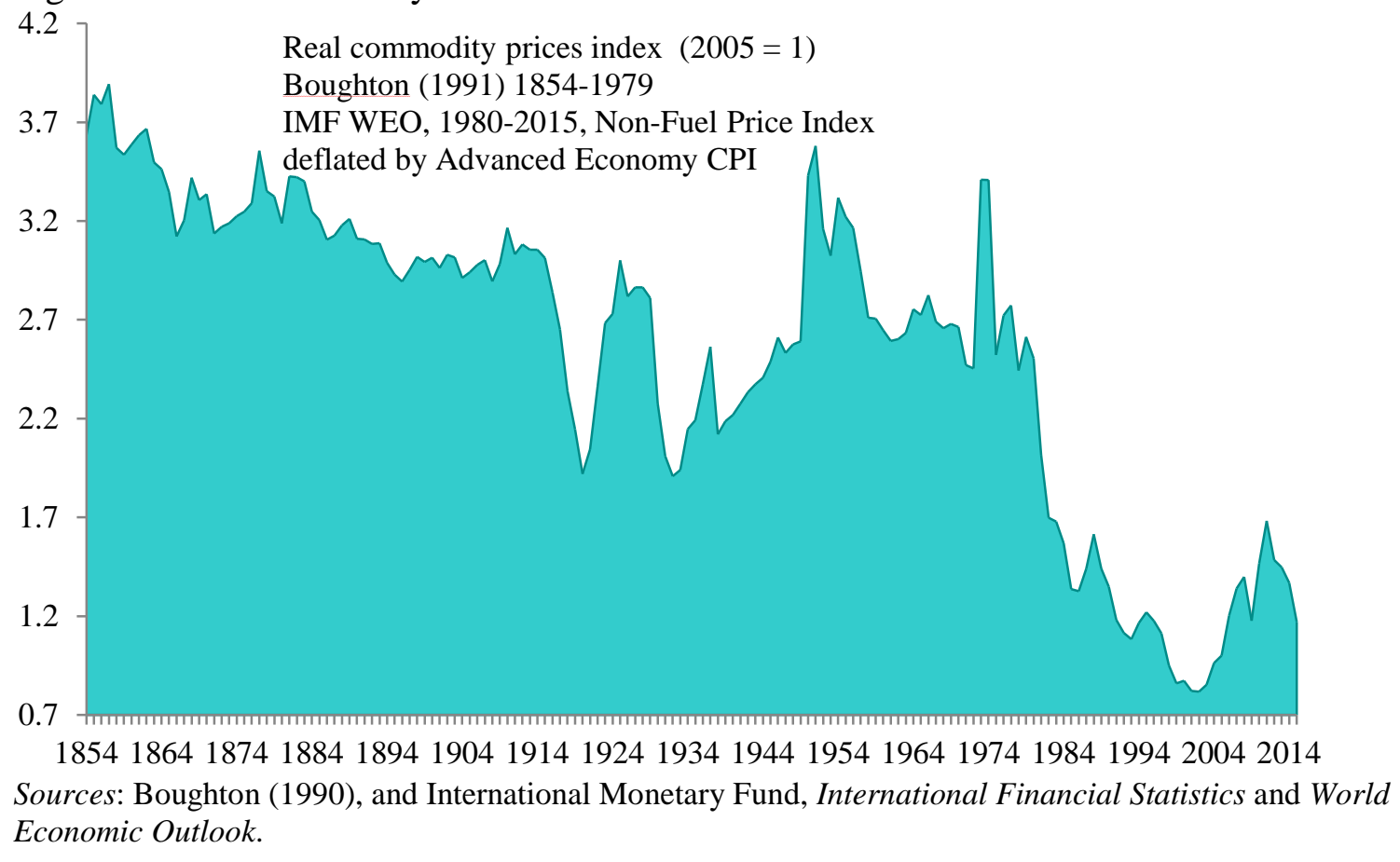

Unlike prior commodity price booms, a number of Latin American governments did, on the whole, manage to avoid pro-cyclical fiscal policies (at least in the earlier stage of the commodity boom). ${ }^{35}$ Furthermore, governments had already re-oriented their financing strategy inward, avoiding their historic reliance on external debt. But, as we know from Carlos, fiscal prudence during the boom is necessary, but seldom sufficient. Borrowing at low international interest rates at a time during which their currencies were either stable or appreciating against the dollar was a tempting proposition for the private firms and banks to borrow abroad. As the capital inflow bonanza matured, some of its usual less attractive characteristics became manifest. Current account deficits

\footnotetext{
${ }^{35}$ Unfortunately, Brazil, took several steps back on this front.
} 
reappeared; as did domestic credit booms and currency overvaluation. ${ }^{36}$ Growth began to slow.

Much of Latin America (and developing countries in general) saw the prosperous phase of their cycle moderate or come to an end altogether during the spring of 2013, as the US Federal Reserve announced its plans to gradually withdraw from its exceptionally accommodative policies of last few years. The prospect of rising world interest rates also arrived with a downturn in global commodity markets. While some countries benefitted from declining oil prices, the dominant effect of tumbling commodities prices was unmistakably negative. Many Latin American currencies began to depreciate in earnest. $^{37}$

Interest rate cycles in financial centers and booms and busts in commodity prices are "classic" external factors through much of history. The emergence of China as an economic power and engine of growth for the developing world, on the other hand, is of fairly modern vintage. China's investment-led growth fueled the boom phase of the cycle for emerging economies and its unfolding slowdown (along with its efforts to re-orient to domestic consumption) is now contributing to the economic downturn evident in many emerging markets, Latin America included.

Last, but certainly not least, a sharply appreciating dollar in early 2015 on the heels of what (in many cases) were already significant domestic currency depreciations increases external debt burdens. The old liability dollarization problem resurfaces (Diaz Alejandro, 1965). In his world, large depreciations (devaluations) can be contractionary

${ }^{36}$ Brazil's rapidly rising volume of nonperforming consumer loans is evidence of the boom's legacy. Barchfield ( June 15,2015) reports that an estimated 30 percent of disposable income now goes to debt (including credit cards) servicing; the comparable figure cited for the US is 5 percent..

${ }^{37}$ The Brazilian real has depreciated by about 60 percent since March 2013; the Colombian peso almost 50 percent.. 
because of the aforementioned adverse balance sheet effects or because these exchange rate swings are redistributive. Carlos' (1963) framework suggests that a depreciation will lower aggregate consumption, as it shifts the purchasing power to the exporters/capitalists (who have a low propensity to consume) while it lowers the real purchasing power of wage earners (who have a high propensity to consume). ${ }^{38}$

At a conjuncture such as this, one hopes that Carlos description of the state of affairs in the region in the early 1980s is not one we will have to apply to the here and now.

Blaming victims is an appealing evasion of responsibility, especially when the victims are far from virtuous. But when sins are as heterogeneous as those of the Latin American regimes of 1980, one wonders how well the exemplary mass punishment fits the alleged individual crime. Most Latin American economies, for a variety of domestic and external reasons, in 1980-81 faced the need for reform and adjustment to the new international economic environment. However, the response was slow, and policy errors continued to be made. Yet the incompetence and torpor of policymakers do not fully explain the depth of the depression of the early 1980s in Latin America and the mediocre outlook for recovery. ${ }^{39}$

The bonanza decade of 2003-2013 is over and we are not in Kansas anymore.

\footnotetext{
${ }^{38}$ On the issue of whether currency depreciations were output enhancing or not (as in many other matters), he kept and open mind. Diaz Alejandro (1965), for instance presents the case for expansionary effects of a devaluation/depreciation.

${ }^{39}$ Diaz Alejandro (1983).
} 


\section{References}

\section{Díaz Alejandro bibliography}

Bacha, Edmar Lisboa and Carlos F. Diaz Alejandro, (1982) “International Financial Intermediation: A Long and Tropical View,” Essays in Financial Intermediation: A Long and Tropical View,” Essays in International Finance No. 147, Princeton University.

Brecher, Richard A. and Carlos F. Diaz-Alejandro, (1977). “Tariffs, Foreign Capital, and Immiserizing Growth,” Journal of International Economics Vol. 7(4), 317-322.

Cooper, Richard N., Carlos F. Diaz-Alejandro, and Rudiger Dornbusch, (1983). "Some Aspects of the 1982-83 Brazilian Payments Crisis,” Brookings Papers on Economic Activity, No.2, (1983), 515-552.

Díaz Alejandro, Carlos F. (1963). "A Note on the Impact of Devaluation and the Redistributive Effect." The Journal of Political Economy: 577-580.

Díaz Alejandro, Carlos F. (1965). Exchange Rate Devaluation in a Semi-Industrialized Country: The Experience of Argentina, 1955-1961, (Cambridge, MA: MIT Press).

Diaz Alejandro, Carlos F.,(1970). Essays on the Economic History of the Argentine Republic. (New Haven: Yale University Press).

Diaz Alejandro, Carlos F., (1975). "Less Developed Countries and the Post-1971 International Financial System”, Essays in International Finance No. 108, Princeton University.

Diaz Alejandro, Carlos F., (1976) Foreign Trade Regimes and Economic Development: Colombia, (Cambridge: National Bureau of Economic Research)

Diaz Alejandro, Carlos F.,(1981). "Southern Cone Stabilization Plans,” in William Cline (ed.) Economic Stabilization in Developing Countries (Washington DC: The Brookings Institution).

Diaz Alejandro, Carlos F., (1983) “Stories of the 1930s for the 1980s” (1983). In Pedro Aspe, et al. (eds.) Financial Policies and the World Capital Market: The Problem of Latin American Countries, Chicago: The University of Chicago Press for the NBER.

Diaz Alejandro, Carlos F., (1984) “Latin American Debt: I Don’t Think We are in Kansas Anymore”, Brookings Papers on Economic Activity, Vol. 2, 335-403.

Diaz Alejandro, Carlos F., (1985) “Good-bye Financial Repression, Hello Financial Crash,” Journal of Development Economics 19, 1-24. 
Diaz Alejandro, Carlos F. and Gerald K. Helleiner, (1982). "Handmaiden in Distress: World Trade in the 1980s." North-South Institute, Ottawa, Overseas Development Council, Washington DC, and Overseas Development Institute, London.

\section{Others}

Barchfield, Jenny (2015) Amid Brazil's economic crisis, consumers struggle to pay off debts run up in the good times, Fox News, June 15.

Calvo, Guillermo A. (1986). “Temporary Stabilization: Predetermined Exchange Rates,” Journal of Political Economy, 94: 6 (December),1319-1329.

Calvo, Guillermo A. (1989). "Incredible Reforms," Debt, Stabilization and Development, edited by Guillermo Calvo, Ronald Findlay, Pentti Kouri, and Jorge Braga de Macedo, (Basil Blackwell, Oxford).

Calvo, Guillermo A., Leonardo Leiderman, and Carmen M. Reinhart (1993). "Capital Inflows and Real Exchange Rate Appreciation in Latin America: The Role of External Factors”, IMF Staff Papers, Vol. 40(1), March, 108-151.

Calvo, Guillermo A. Alejandro Izquierdo, Luis-Fernando Mejía, (2008). "Systemic Sudden Stops: The Relevance of Balance-Sheet Effects and Financial Integration," NBER Working Paper 14026, May.

Della Paolera, Gerardo, and Alan M. Taylor, (2001). Straining at the Anchor: The Argentina Currency Board and the Search for Macroeconomic Stability, 1880-1935, (Chicago: University of Chicago Press for the NBER).

Dornbusch, Rudiger (1986). Dollar, Debt, and Deficits, (Cambridge, MA: MIT Press).

Dornbusch, Rudiger, Alejandro Werner (1994). "Mexico: stabilization, reform, and no growth." Brookings papers on economic activity (1994): 253-315.

Edwards, Sebastian (1989). Real Exchange Rates, Devaluation, and Adjustment, (Cambridge: MIT Press).

Fisher, Daniel (2010). “The Global Debt Bomb”, Forbes, January 20.

Frankel, Jeffrey, and George Saravelos. (2012). "Can leading indicators assess country vulnerability? Evidence from the 2008-09 global financial crisis." Journal of International Economics 87.2: 216-231.

Gourinchas, Pierre-Olivier, and Maurice Obstfeld. "Stories of the Twentieth Century for the Twenty-First." American Economic Journal: Macroeconomics 4.1 (2012): 226-265. 
International Monetary Fund, International Financial Statistics, various issues.

International Monetary Fund, World Economic Outlook, various issues.

Kaminsky, Graciela L., and Alfredo Pereira. (1996). "The Debt Crisis: Lessons of the 1980s for the 1990s." Journal of Development Economics 50.1: 1-24.

Kaminsky, Graciela L. and Carmen M. Reinhart, (1999). "The Twin Crises: The Causes of Banking and Balance of Payments Problems,"American Economic Review, Vol. 89(3), June, 473-500.

Kindleberger, Charles P., (1989). "From Graduate Student to Professional Peer: An Appreciation of Carlos F. Díaz-Alejandro,” Debt, Stabilization and Development, edited by Guillermo Calvo, Ronald Findlay, Pentti Kouri, and Jorge Braga de Macedo, (Basil Blackwell, Oxford).

Lane, Philip R. and Gian Maria Milesi-Ferretti (2010), "The External Wealth of Nations Mark II: Revised Extended Estimates of Foreign Assets and Liabilities, 1970-2004" in Crowe et. a. eds., Macrofinancial Linkages: Trends, Crises, and Policies, Washington DC: International Monetary Fund.

Littlefield, H. M. (1964). “The Wizard of Oz: Parable on Populism” American Quarterly, Vol. 16, (Spring), 47-58.

Mendoza, Enrique G., and Marco E. Terrones. (2012). An anatomy of credit booms and their demise. No. w18379. National Bureau of Economic Research.

Obstfeld, Maurice, (2014). "Never Say Never: Commentary on a Policymaker’s Reflections," IMF Economic Review, Vol. 62, July, 656-693.

Reinhart, Carmen M. and Vincent R. Reinhart, (2010). “After the Fall,” in Proceedings, Federal Reserve Bank of Kansas City Economic Policy Symposium, Macroeconomic Challenges: The Decade Ahead, 2010, 17-60.

Reinhart, Carmen M., Kenneth Rogoff, (2009). This Time Is Different: Eight Centuries of Financial Folly (Princeton: Princeton University Press).

Reinhart, Carmen M., Kenneth Rogoff (2014). "Recovery from Financial Crises: Evidence from 100 Episodes,” American Economic Review, Vol. 104(5), May, 50-55.

Sachs, Jeffrey, (1984) Comments on: “Latin American Debt: I Don’t Think We are in Kansas Anymore”, Brookings Papers on Economic Activity, Vol. 2, 335-403.

Statistics Iceland. http://www.statice.is/ 
Végh, Carlos A (1992). "Stopping high inflation: an analytical overview." Staff PapersInternational Monetary Fund (1992): 626-695.

Velasco, Andres (1985). "Financial Crises and Balance of Payments Crisis: A Simple Model of the Southern Cone,” Journal of Development Economics 27: 263-283.

World Bank, Quarterly External Debt Statistic (QEDS), various. 
Table A.1 Credit Ratings on Long-term Obligations

\begin{tabular}{|c|c|c|}
\hline Moody‘s & S\&P or Fitch & Explanation of rating \\
\hline \multicolumn{3}{|c|}{ Investment grade ratings } \\
\hline Aaа & AAA & Highest grade, lowest risk \\
\hline Aa & AA & High grade, low risk \\
\hline A & A & $\begin{array}{l}\text { Above average grade, relatively } \\
\text { low risk }\end{array}$ \\
\hline Ваa & $\mathrm{BBB}$ & Average grade, medium risk \\
\hline \multicolumn{3}{|c|}{ Speculative grade ratings } \\
\hline $\mathrm{Ba}$ & $\mathrm{BB}$ & Payment likely, but uncertain \\
\hline B & B & $\begin{array}{l}\text { Currently able to pay, risk of } \\
\text { future default }\end{array}$ \\
\hline Caa & CCC & $\begin{array}{l}\text { Poor liquidity and clear risk of } \\
\text { default }\end{array}$ \\
\hline $\mathrm{Ca}$ & $\mathrm{CC}$ & $\begin{array}{l}\text { Very doubtful liquidity; frequent } \\
\text { default }\end{array}$ \\
\hline \multirow[t]{2}{*}{$\mathrm{C}$} & $\mathrm{C}$ & $\begin{array}{l}\text { Lowest grade; extremely poor } \\
\text { outlook for repayment }\end{array}$ \\
\hline & $\mathrm{D}$ & In default \\
\hline
\end{tabular}


Table A.2. Domestic Bank Credit/GDP 10 Years Before and After Severe Financial Crises: Fifteen Post WWII Episodes

\begin{tabular}{|c|c|c|c|c|c|c|c|c|}
\hline \multirow{3}{*}{$\begin{array}{l}\text { Country and } \\
\text { crisis year }\end{array}$} & \multicolumn{4}{|c|}{ Domestic credit surges } & \multicolumn{4}{|c|}{ Post-crisis deleveraging } \\
\hline & \multicolumn{2}{|c|}{$\begin{array}{l}\text { Minimum credit } \\
\text { ratio in } 10 \text { years } \\
\text { prior to crisis, }\end{array}$} & \multicolumn{2}{|c|}{$\begin{array}{l}\text { Maximum credit } \\
\text { ratio around the } \\
\text { crisis }\end{array}$} & \multirow{2}{*}{$\begin{array}{l}\text { Difference } \\
\text { maximum } \\
\text { less pre- } \\
\text { crisis } \\
\text { minimum } \\
(5)=(3)-(1)\end{array}$} & \multicolumn{2}{|c|}{$\begin{array}{l}\text { Lowest ratio reached } \\
\text { in the } 10 \text { years } \\
\text { following the crisis }\end{array}$} & \multirow{2}{*}{$\begin{array}{l}\text { Difference } \\
\text { post-crisis } \\
\text { minimum less } \\
\text { maximum } \\
(8)=(6)-(3)\end{array}$} \\
\hline & $\begin{array}{c}\text { level } \\
(1)\end{array}$ & $\begin{array}{c}\text { year } \\
(2) \\
\end{array}$ & $\begin{array}{l}\text { level } \\
(3)\end{array}$ & $\begin{array}{c}\text { year } \\
(4) \\
\end{array}$ & & $\begin{array}{r}\text { level } \\
(6)\end{array}$ & $\begin{array}{l}\text { year } \\
(7)\end{array}$ & \\
\hline \multicolumn{9}{|c|}{ Advanced economies } \\
\hline Spain, 1977 & 65.6 & 1967 & 102.5 & 1976 & 36.8 & 94.2 & 1980 & -8.2 \\
\hline Norway, 1987 & 130.0 & 1980 & 162.4 & 1988 & 32.4 & 123.7 & 1994 & -38.7 \\
\hline Finland, 1991 & 46.4 & 1981 & 92.9 & 1991 & 46.5 & 54.9 & 1997 & -38.0 \\
\hline Sweden, 1991 & 56.1 & 1985 & 72.9 & 1989 & 16.8 & 45.0 & 1996 & -27.9 \\
\hline Japan, 1992 & 193.8 & 1982 & 260.5 & 1996 & 66.7 & 221.9 & 1997 & -38.6 \\
\hline \multicolumn{9}{|c|}{ Emerging economies: The Asian Crisis, 1997} \\
\hline Indonesia* & 23.6 & 1987 & 62.1 & 1999 & 38.4 & 40.6 & 2007 & -21.5 \\
\hline Korea** & 50.5 & 1988 & 64.1 & 1997 & 13.6 & \multicolumn{3}{|c|}{$\begin{array}{c}\text { No post-crisis deleveraging through } \\
2008\end{array}$} \\
\hline Malaysia & 72.7 & 1990 & 163.4 & 1997 & 90.7 & 113.8 & 2007 & -49.6 \\
\hline Philippines & 19.5 & 1991 & 78.5 & 1997 & 59.0 & 40.9 & 2007 & -37.7 \\
\hline Thailand** & 84.1 & 1988 & 177.6 & 1997 & 93.5 & 104.2 & 2007 & -73.4 \\
\hline \multicolumn{9}{|c|}{ Emerging economies: Other episodes } \\
\hline Argentina, 2001* & 22.3 & 1992 & 61.9 & 2002 & 39.7 & 23.8 & 2008 & -38.1 \\
\hline Chile, 1981* & 31.1 & 1971 & 114.7 & 1985 & 83.5 & 60.5 & 1991 & -53.9 \\
\hline Colombia, 1998 & 29.2 & 1992 & 42.5 & 1998 & 13.2 & 35.7 & 2008 & -6.8 \\
\hline Mexico, 1994** & 37.3 & 1990 & 53.0 & 1997 & 15.7 & 33.2 & 2005 & -19.8 \\
\hline Turkey, 2001** & 22.5 & 1991 & 52.7 & 2001 & 30.3 & 41.4 & 2004 & -11.4 \\
\hline \multicolumn{9}{|c|}{ Memorandum item } \\
\hline Median for 15 & isodes & & & & 38.4 & & & -37.7 \\
\hline
\end{tabular}

Notes: An asterisk $(*)$ indicates a sovereign default (or restructuring) took place during or shortly after that episode; a double asterisk $(* *)$ are near-default episodes, as defined in Reinhart (2010), where a default was avoided with major international assistance. Italics denote that the deleveraging process is ongoing according to the latest available data.

Sources: International Financial Statistics, International Monetary Fund, various issues, Norges Bank (website), Reinhart and Rogoff (2009), Reinhart (2010), and authors”' calculations. 